\title{
Erratum to: Home-range use patterns and movements of the Siberian flying squirrel in urban forests: effects of habitat composition and connectivity
}

Sanna Mäkeläinen ${ }^{1 *}$, Henrik J. de Knegt ${ }^{2,3}$, Otso Ovaskainen² and Ilpo K. Hanski ${ }^{1}$

After publication of this study [1], we noticed that Fig. 1 was not correctly processed during copyediting. The original version of this article was corrected. The publisher apologizes for any inconvenience caused. Please see the corrected Fig. 1 below:

\begin{abstract}
Author details
${ }^{1}$ Finnish Museum of Natural History LUOMUS, University of Helsinki, P. O. Box 17 (P. Rautatiekatu 13), Helsinki Fl-00014, Finland. ${ }^{2}$ Department of Biosciences, University of Helsinki, P. O. Box 65 (Viikinkaari 1), Helsinki Fl-00014, Finland. ${ }^{3}$ Current address: Resource Ecology Group, Wageningen University, Droevendaalsesteeg 3a, Wageningen 6708 PB, The Netherlands.
\end{abstract}

Received: 10 March 2016 Accepted: 30 March 2016

Published online: 14 April 2016

\section{Reference}

1. Mäkeläinen S, de Knegt HJ, Ovaskainen O, Hanski IK. Home-range use patterns and movements of the Siberian flying squirrel in urban forests: Effects of habitat composition and connectivity. Mov Ecol. 2016;4:5.

\footnotetext{
* Correspondence: sanna.makelainen@helsinki.fi

${ }^{1}$ Finnish Museum of Natural History LUOMUS, University of Helsinki, P. O. Box 17 (P. Rautatiekatu 13), Helsinki Fl-00014, Finland

Full list of author information is available at the end of the article
}

Submit your next manuscript to BioMed Central and we will help you at every step:

- We accept pre-submission inquiries

- Our selector tool helps you to find the most relevant journal

- We provide round the clock customer support

- Convenient online submission

- Thorough peer review

- Inclusion in PubMed and all major indexing services

- Maximum visibility for your research

Submit your manuscript at www.biomedcentral.com/submit
() Biomed Central 


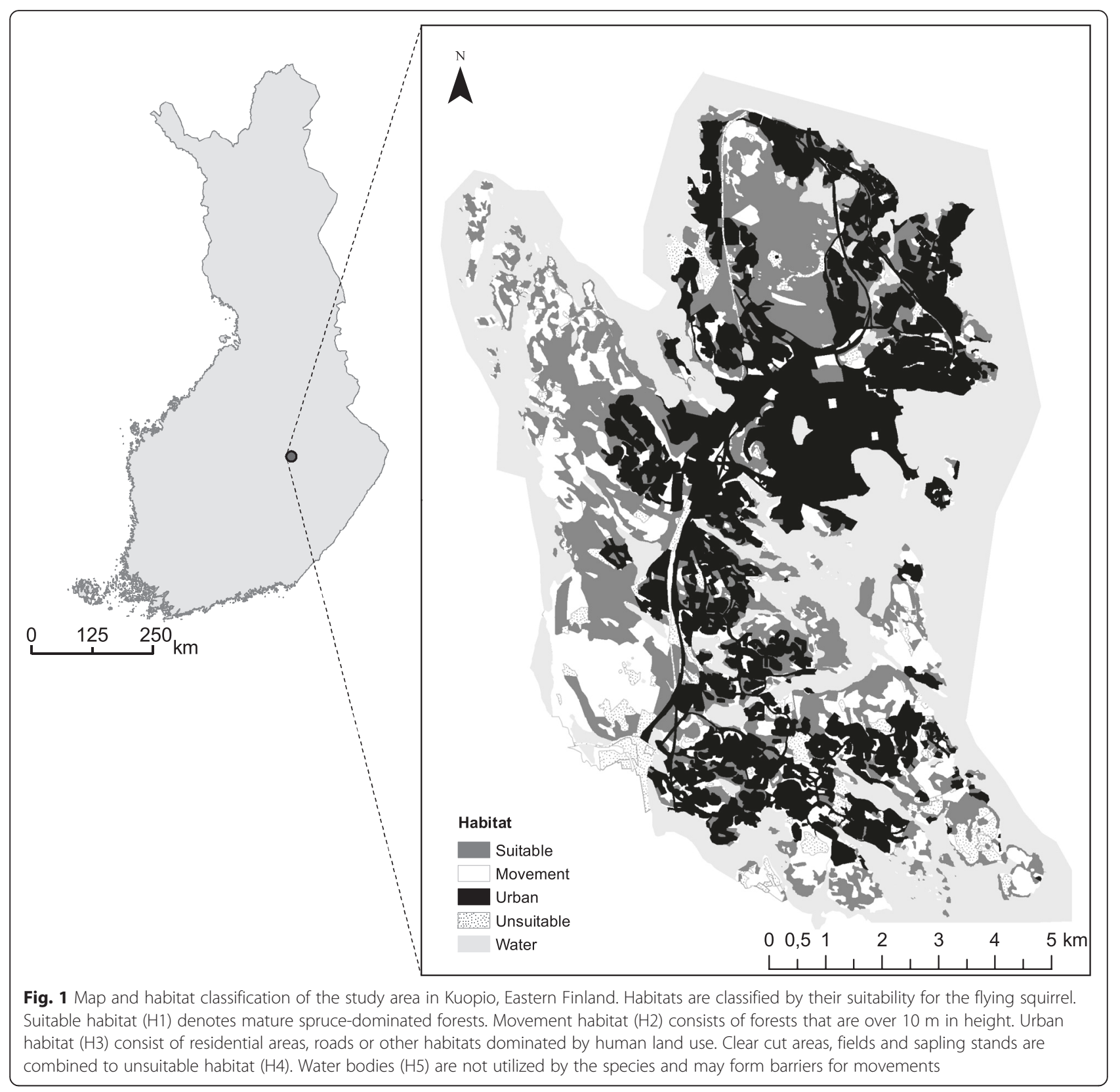

